\title{
Articles
}

\section{A Critical Review of the Canadian Empirical Literature: Documenting Generation 1.5's K-16 Trajectories}

Bruce Garnett

Little empirical research has ever systematically documented the academic trajectories of Generation 1.5 in Canadian schools. Indeed, this label has not even been used to define the population of interest in the studies reviewed here. Nonetheless, some earlier work, along with more current studies made possible by recent availability of data, has created a small blossoming of relevant literature that might now be critically synthesized. Therefore, this report synthesizes 17 available largescale Canadian empirical studies that examine the outcomes and trajectories of immigrant youth in Canadian K-12 schools and university. Despite differences in variables across the studies, this article finds that school outcomes vary predictably among ethnocultural groups and by English-language proficiency. It also finds that the role of socioeconomic status in explaining these differences is not yet clear. It appears that some immigrant groups are underserved and that teachers may be underprepared for classrooms of linguistic and ethnocultural diversity. Policy implications and further research directions are discussed.

Peu de recherche empirique a documenté de façon systématique les trajectoires académiques de la génération 1,5 dans les écoles canadiennes. En effet, on n'a même pas employé cette étiquette pour définir la population ciblée dans les recherches que nous étudions ici. Toutefois, quelques recherches antérieures et des études actuelles rendues possibles par la disponibilité récente de données ont provoqué l'apparition de recherches pertinentes qui peuvent être mises en rapport de façon éclairée. Ainsi, ce rapport examine 17 études empiriques canadiennes à grande échelle portant sur les résultats et les trajectoires des jeunes immigrants dans des écoles K-12 et des universités au Canada. Malgré les différences dans les variables d'une étude à l'autre, on a trouvé que les résultats scolaires varient de façon prévisible selon les groupes ethnoculturels et la compétence en anglais. On a également trouvé que le rôle que joue le statut socioéconomique dans ces différences n'est toujours pas clair. Il parait que certains groupes immigrants sont mal desservis et que les enseignants peuvent être mal préparés pour les classes affichant une diversité linguistique et ethnoculturelle. On discute des incidences sur les politiques générales et des orientations pour la recherche à l'avenir. 
Little empirical research has ever systematically documented the academic trajectories of Generation 1.5 in Canadian schools. Indeed, this label has not even been used to define the population of interest in the studies reviewed here. Nonetheless, some earlier work, along with more current studies made possible by recent availability of data, has created a small blossoming of relevant literature that might now be critically synthesized. Despite a broad common concern with academic achievement, however, this synthesis is complicated by differences among studies in (a) indicators and definitions of a population that we might refer to as Generation 1.5; (b) relevant independent variables; and (c) outcome measures.

Nonetheless, the topic merits attention, as the principal outcomes of adaptation among young immigrants are educational attainment and graduation versus dropout (Portes \& Hao, 2004). Therefore, this report synthesizes 17 available large-scale Canadian empirical studies that examine the outcomes and trajectories of immigrant youth in Canadian K-12 schools and university. These children of immigrants, who have experienced some or all of their K-12 schooling in Canada, constitute what we for our purposes might call Generation 1.5. It then draws on this research base and complementary literature to address the following questions about Generation 1.5's academic integration.

- What does the literature suggest are the patterns in Generation 1.5's school achievement?

- Given the evidence, what appear to be our weaknesses?

- Given the evidence, what appear to be the key policies and practices that do or could produce favorable outcomes?

- What are future research directions?

\section{The Selection of Studies}

Table 1 summarizes the 17 studies retrieved. We selected only empirical work published in English that documents the trajectories of Generation $1.5 \mathrm{~s}$ in Canadian high schools and beyond through university over the past 25 years. Generation 1.5 has been indicated by immigrants, children of immigrants, ESL students, and non-native English and French speakers. Owing to the scant availability of studies, some important non-peer-reviewed publications are included along with the peer-reviewed studies. These are the Radwanski (1987) report, Gunderson's (2007) widely read and discussed book, and a large report coordinated by McAndrew (McAndrew, Ledent, \& AitSaid, 2009).

This latter report, commissioned by Citizenship and Immigration Canada and the Canadian Council on Learning, subsumes three studies that describe trajectories of comparable groups of immigrant students in Montreal, Toronto, and Vancouver undertaken by separate research teams at each site. 


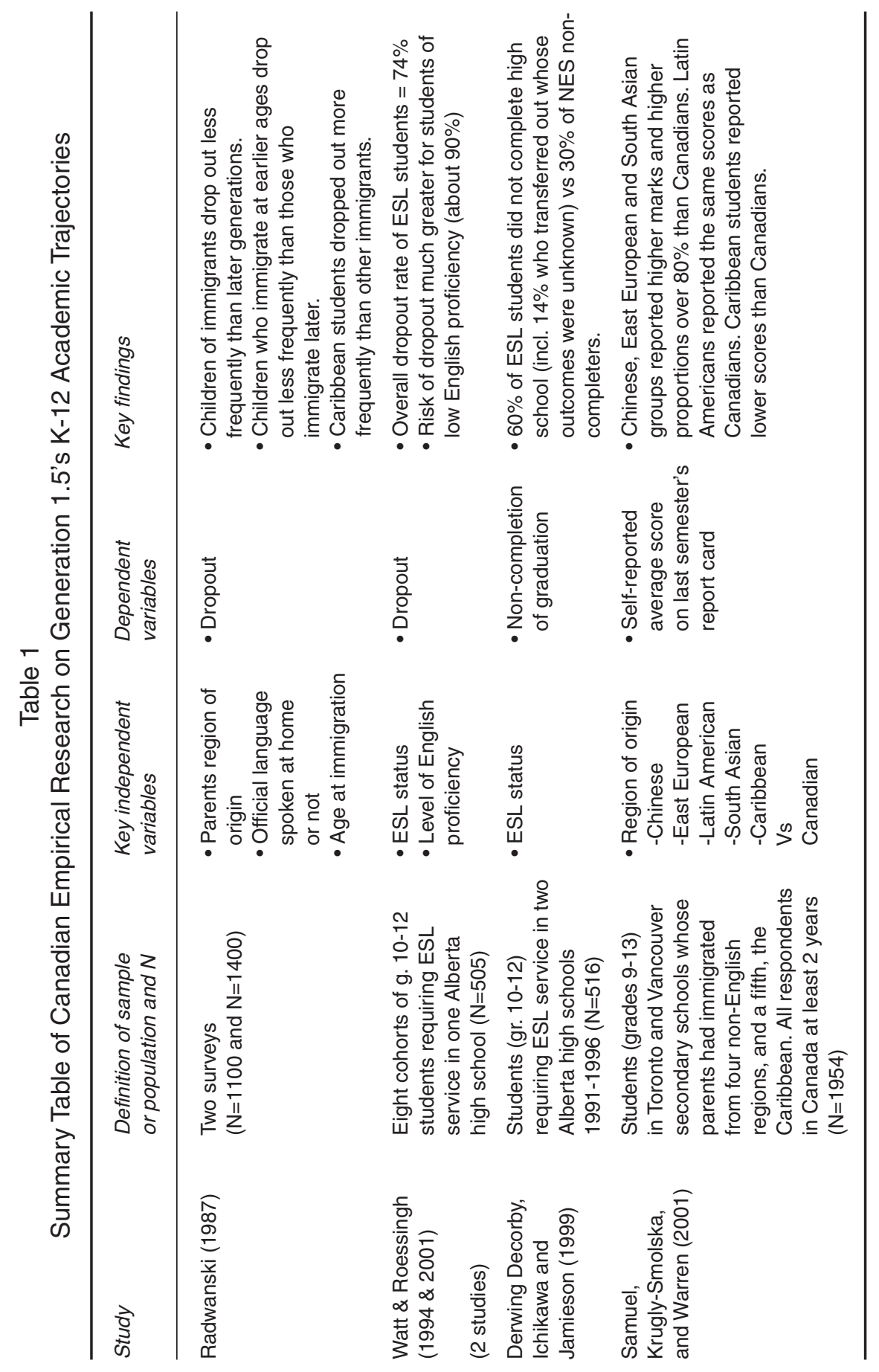




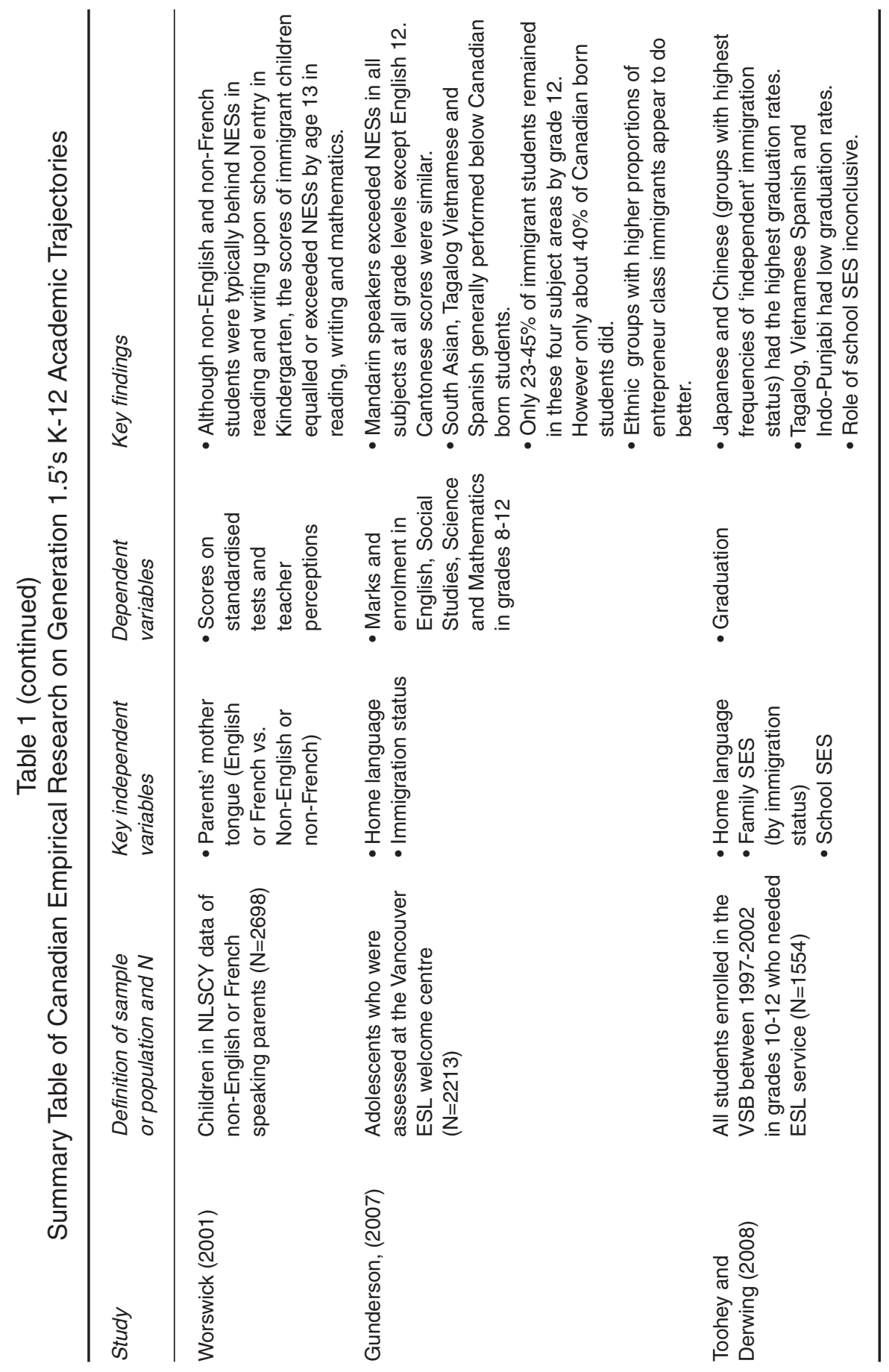




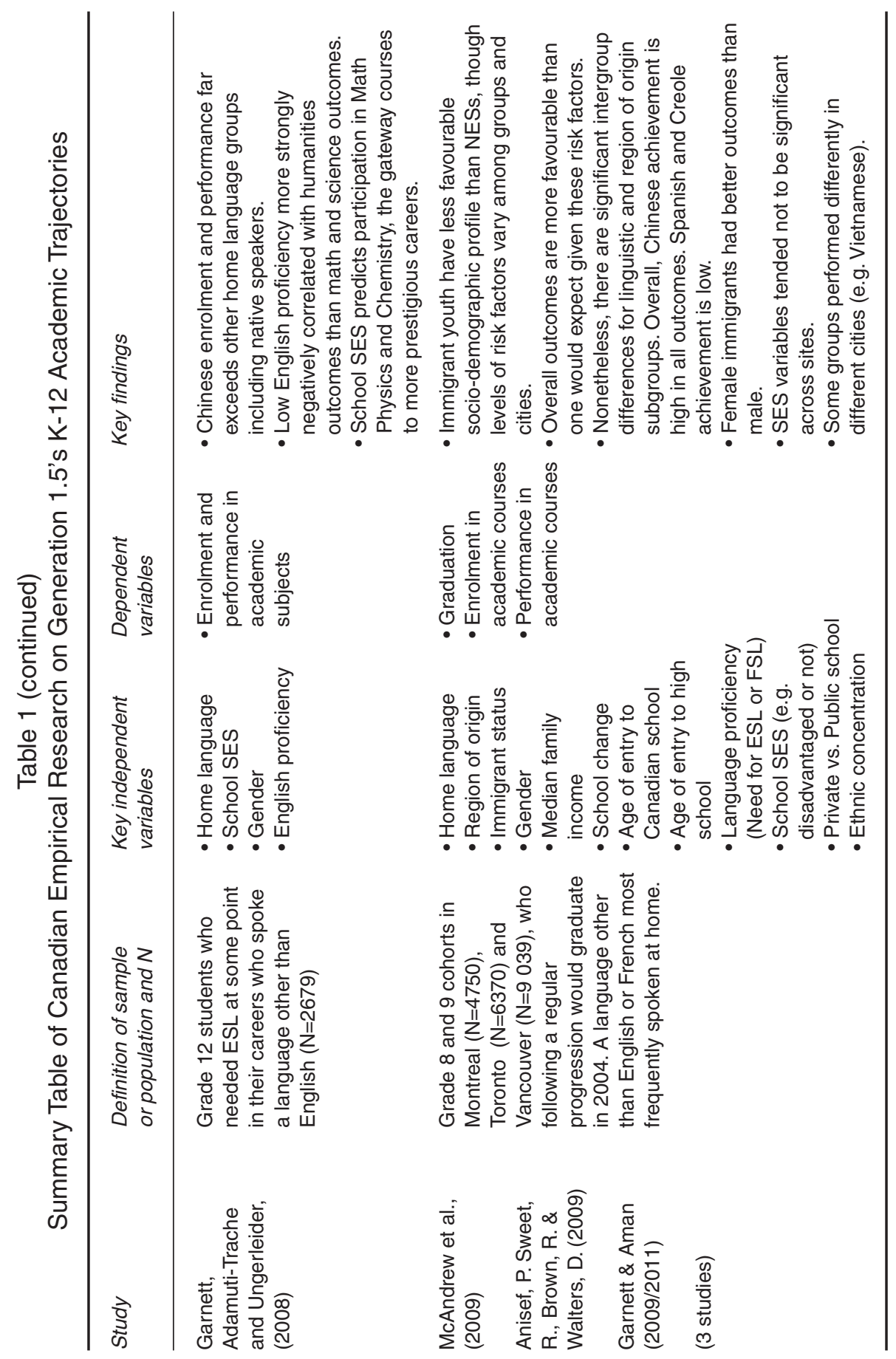




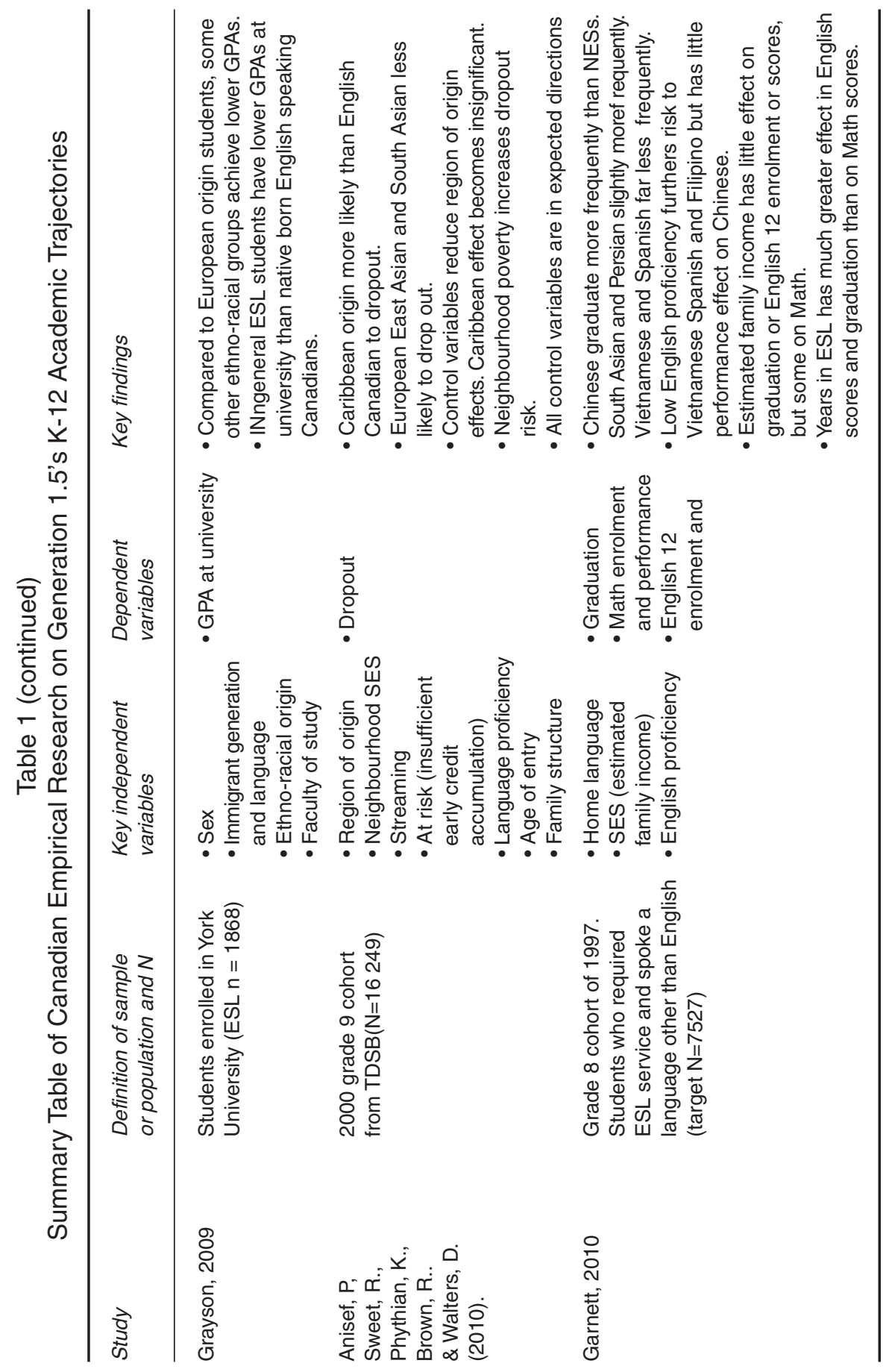




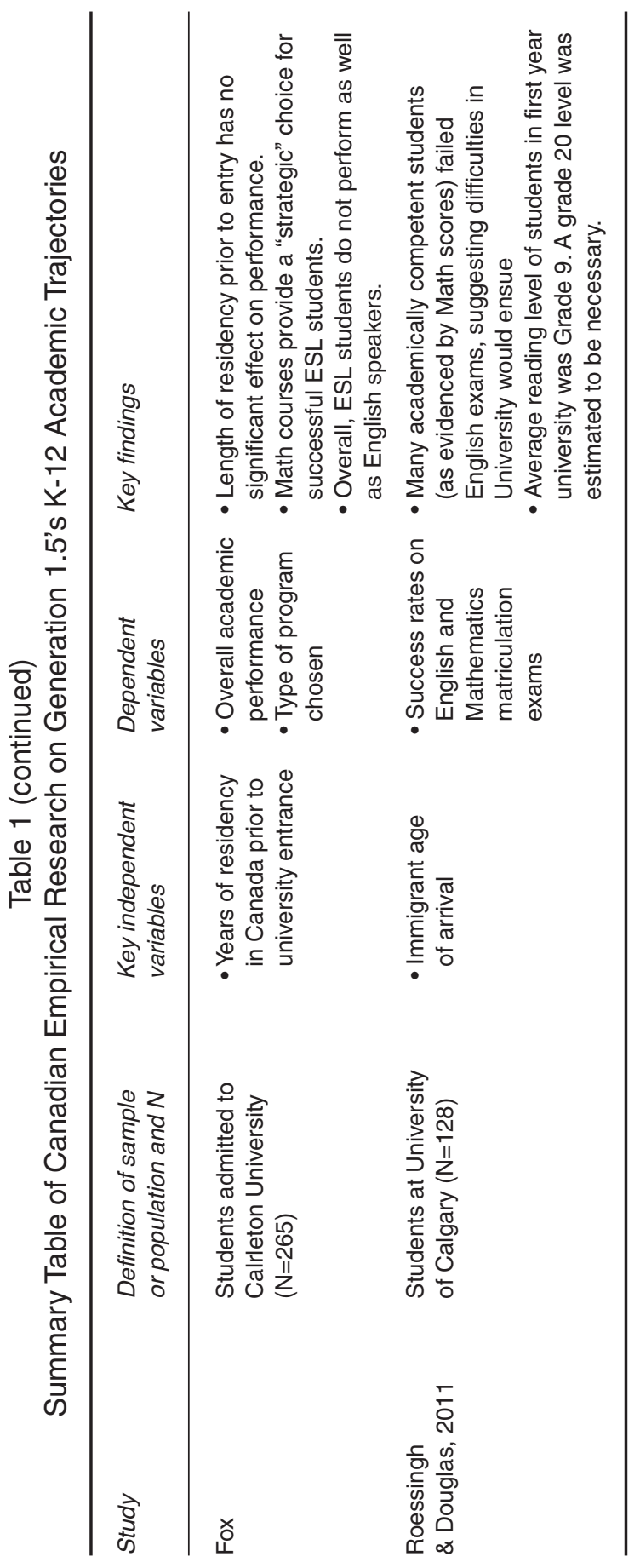




\section{The Patterns of Generation 1.5's Achievement}

Varying definitions and operationalizations of Generation 1.5, or its proxy definitions, yield fairly diverse results across studies and hinder understanding of the multiple realities of students subsumed by this label. Immigrants may be children who arrive at Canadian schools after beginning educational programs elsewhere, or they may be children of immigrants who have only attended Canadian schools. They may be fluent, illiterate, or any point between in the language of instruction and/or the language of their parents. Like all students, they come from a variety of family and socioeconomic backgrounds. Perhaps most important, they arrive from every region of the globe and its systems of education and values.

These differences are critical predictors of Canadian academic success and are often lost in reports that aggregate all students into a single category such as immigrant or ESL. Reports from the British Columbia Ministry of Education and many of the studies here tend to show that overall, the outcomes of Generation 1.5 equal or exceed those of later generations (Garnett, 2010; Garnett, Adamuti-Trache, \& Ungerleider, 2008; Gunderson, 2007). However, the major observation is: while generation 1.5 students, on average, appear as successful as Canadian-born students, outcomes of identifiable subsets of students under the Generation 1.5 label vary widely. The major differences are as follows.

\section{Outcomes Vary Predictably by Ethnocultural Group}

Much recent research shows distinct patterns of academic success and vulnerability across ethnocultural groups. Chinese students demonstrate a consistent pattern of success across multiple studies. In Garnett (2010), Chinese speakers graduated more frequently than all other groups including native speakers. Their enrollment and performance in mathematics and science were also higher than those of any other group. Garnett and Aman $(2009,2011)$ replicated these findings for another cohort. Furthermore, Garnett et al. (2008) discovered that among grade 12 students, Chinese students had far greater odds of participating in the sciences than any other ESL group and that no other ESL group could equal their mean scores in math, English, or overall GPAs.

The results in all three of Garnett's studies $(2008,2009,2010)$ echo Gunderson (2007), who found that speakers of Mandarin and Cantonese had "phenomenally high" mean scores in mathematics, easily outperforming Canadian-born students; they also outperformed all other ethnocultural groups including Canadian-born across almost all academic subjects at all grade levels. Similarly, in Anisef et al. (2010), students from East Asia were the least at risk of dropping out, less so than Canadian-born students, and in Samuel, Krugly-Smolska, and Warren (2001), Chinese students self-reported the highest last-semester mean scores. Finally, Chinese-speakers were among the top mathematics achievers and most frequent graduators in McAndrew et al. (2009) and Anisef et al. (2009). 
Eastern Europeans also appear successful. Romanians graduated and enrolled more and performed better in academic courses than any other group in McAndrew et al. (2009). Russians were top mathematics performers and enrollers in Anisef et al. (2009). Anisef et al. (2010) discovered that Europeans dropped out less frequently than any group except East Asians, and Eastern Europeans self-reported higher mean scores than Canadian-born students in Samuel et al. (2001).

Other ethnocultural groups also generally emerge as successful although they do not appear as frequently in the literature. Koreans and Persians have high graduation rates and mathematics and science scores in Garnett (2010), Garnett and Aman (2009), and Garnett et al. (2008; Persians not studied). Persians exhibit average outcomes in Anisef et al. (2009) and McAndrew et al. (2009).

The various groups subsumed by the South Asian label generally have average to favorable outcomes. South Asians graduated more frequently than NESs in Garnett (2010) as did Punjabi-speakers in Garnett and Aman (2009, 2011). South Asians self-reported mean scores higher than those of the Canadian-born in Samuel et al. (2001) and dropped out less frequently than Canadians in Anisef et al. (2010). Math scores and participation for Tamil- and Urdu-speakers were positive in Anisef et al. (2009). By contrast, Tamil outcomes were poor in McAndrew et al. (2009) as were Hindi outcomes in Garnett and Aman (2009). South Asian enrollment and performance in Garnett et al. (2008) is among the lower groups, and Indo-Punjabi-speakers graduate at low rates in Toohey and Derwing (2008).

By contrast, a number of groups appear fairly consistently vulnerable to poor academic outcomes. The various populations labeled Spanish had the lowest or among the lowest graduation rates and/or academic enrollment and mean scores in Garnett (2010), Garnett and Aman (2011), Garnett et al. (2008), Gunderson (2007), Anisef et al. (2009), Toohey and Derwing (2008), and McAndrew et al. (2009). Similarly, Latin American students are among those most at risk of dropout in Anisef et al. (2010) and self-reported low marks in Samuel et al. (2001).

Other groups that demonstrate an ongoing pattern of vulnerability include those from the Caribbean. They were part of the biggest identifiable dropout group in Radwanski (1987). They self-reported the lowest scores of all groups in Samuel et al. (2001) and exhibited the highest dropout rates in Anisef et al. (2010). Similarly, Creole-speakers had the lowest graduation rates in McAndrew et al. (2009), and in McAndrew et al.'s (2005) study of Black youth in Montreal, which did not focus specifically on immigrants, Creole- and English-speaking youths' graduation rates within seven years of starting secondary school were only $40 \%$.

Vietnamese students had lower graduation rates than NESs and/or most other ethnocultural groups in Garnett (2010), Garnett and Aman $(2009,2011)$, 
and Toohey and Derwing (2008). They disappeared dramatically from the data tracking enrollment in academic subjects in Gunderson (2007). Despite average-to-strong enrollment in academic subjects in Garnett et al. (2008), Vietnamese mean scores were well below those of other ethnic groups and the NES baseline. However, Vietnamese outcomes approached the NES baseline in Toronto and exceeded it in Montreal (Anisef et al., 2009; McAndrew et al., 2009). Portuguese students' results are also generally poor. Portuguese students had the lowest graduation rates of 10 groups in Anisef et al.; and Brown (2006) and among the lowest in McAndrew et al. (2009). Cummins (1997) reported a similar finding.

Tagalog-speakers' enrollment and mean scores in grade 12 academics in Garnett et al. (2008) were among the lowest of all groups. Filipino beginner ESL graduation rates in Garnett (2010) were lower than the NES baseline and lower than those of other home-language groups in Toohey and Derwing (2008). Filipino-language speakers had lower graduation rates and academic mean scores than NESs in Vancouver (Garnett \& Aman, 2009) and much lower than French-speakers in Montreal (McAndrew et al., 2009). Gunderson showed that Filipinos were among the two groups most likely to drop in academic mean scores once ESL support had been removed in grade 10.

Although we must remember that the findings across these studies are dominant patterns in ethnocultural groups and not immutable realities, and that the number of studies conducted is small, the variation in trajectories among the various ethnocultural groups has been consistent, and indeed consistent with literature from the US that documents the high achievement of Asian "model minorities" and underachievement and downward mobility of socially and economically disadvantaged immigrant groups such as Haitians and Mexicans (Portes \& Rumbaut, 1990).

\section{Outcomes Generally Vary by English Proficiency Level on Entry to High School}

Many studies indicate the disproportionate risk of dropout and academic failure to students who enter high school with low levels of English proficiency. There is a key difference between immigrants who enter high school with native-like proficiency in the language of instruction and those who do not. When the immigrant population studied required ESL service in high school, results were often troubling.

Radwanski (1987) discovered that ethnic background and immigration did not predict higher levels of dropout. However, in Toronto's 1980 grade 9 cohort, immigrants who had arrived after 1976 dropped out at a rate of 53\%, whereas immigrants who had arrived before 1976 dropped out at a rate of $33 \%$, equal to the mainstream norm. He implied that the former group of students may have lacked the time necessary to become proficient in English. In the two studies conducted by Watt and Roessingh $(1994,2001)$, dropout 
rates for ESL students were remarkably high, $74 \%$ overall. All students in these two studies had below-grade-level English proficiency on entry to high school. However, the students most at risk were beginners in English; over $90 \%$ dropped out in both studies. By contrast, $50 \%$ of advanced students dropped out in both studies. Similarly, $60 \%$ of students enrolled in ESL in high school in Derwing et al. (1999) failed to graduate from high school. Forty percent of students requiring ESL service between grades 8 and 12 did not graduate in Toohey and Derwing (2008).

Garnett (2010) distinguished between beginner ESL students, who needed two or more years of ESL service after entering grade 8 and ESL-ever students who had received ESL service at any stage of their educational programs. Whereas six-year graduation rates in six of eight ethnocultural groups approached or exceeded those of native English-speakers (NES) for ESL-ever, beginner ESL graduation rates fell below NESs in six of eight ethnocultural groups all but Chinese and South Asians markedly so in three of them.

In addition, Garnett (2010) found similar differences in academic enrollment and mean scores at the beginner level. Enrollment in English 12 was 812 percentage points lower for beginners in four ethnocultural groups than it was for all ESL students in the group, and mean scores were 2-6 points lower among beginners in all groups. The least disadvantage was suffered by the Chinese, Koreans, and Persians. Enrollment in Math 12 actually increased at the beginner level for these latter three groups. Mean Math 12 scores among beginner ESL students fell 8-20 points below NES mean scores among most ethnocultural groups. Only Chinese and Korean beginners surpassed NES in Math 12 scores.

These results clarify misconceptions that could arise from studies such as Samuel et al. (2001) and Worswick (2001), which show positive outcomes for immigrant students, but clearly examine populations not characterized by low English proficiency in high school. Similarly, the Ministry of Education in BC frequently reports high ESL graduation rates, but historically has not distinguished between students who require ESL in elementary school and/or high school.

Nonetheless, some important caveats exist to the role of low English proficiency in predicting outcomes. In Garnett (2010) and Gunderson (2007), Chinese ESL students are resilient to the challenges of low English proficiency. In Garnett (2010) in particular, Chinese students' six-year graduation rates dropped only two percentage points at the beginner ESL level. Their participation in mathematics and the sciences increased, as it did for Koreanand Persian-speakers, and their mean scores dropped only one point in these subjects, still higher scores than NESs. In English 12, participation dropped two percentage points and mean scores about three points. In sum, there was minimal quantifiable disadvantage to limited English proficiency among Chinese high school students. 
Conversely, some students most vulnerable to dropout in the Toronto District School Board came from the English-speaking Caribbean (Brown, 2006; Anisef et al., 2009). In Montreal, Caribbean and African francophone immigrants' graduation rates did not equal those of the native-born francophone population, although they exceeded Anglophone and Creole graduation rates from these source regions (McAndrew et al., 2005). The former result suggests that factors other than proficiency in the language of instruction impeded their progress. These results echo Radwanski (1987), who found that English- and French-speaking immigrants from the US, the United Kingdom, and the Caribbean dropped out more frequently than mainstream students.

\section{The Role of SES is Unclear}

The predictive power of socioeconomic status (SES) on schooling outcomes for all populations is well established in the literature (Arnold \& Doctoroff, 2003). Canadian researchers have attempted to explain ethnocultural variations in academic outcomes through SES; however, results to date have provided only the most modest and tentative support for this hypothesis.

Gunderson (2007) divides his sample into three groups by immigrant status; socioeconomically advantaged students from entrepreneur families, (mostly) socioeconomically disadvantaged students from refugee families, and regular immigrants whose SES is, broadly speaking, between the two. He argues that entrepreneur-class immigrants were overrepresented in the high-achieving Mandarin and Cantonese groups (30.2\% and $17.3 \%$ respectively), and the refugees were overrepresented in the poorly performing Vietnamese and Spanish-language groups (53.4\% in the latter case).

The advantaged entrepreneurs exhibited the highest GPAs across subject areas except for Social Studies 12 and English 12, where their GPAs were exceeded by those of regular immigrants. Refugee students had the lowest GPAs of the three groups, particularly in science and mathematics, and regular immigrants' GPAs were generally between those of the other two groups. Furthermore, refugees were the most likely to disappear from the sample by grade 12 , children of entrepreneurs the least likely. As a percentage of the total number of academic course enrollees, children of entrepreneurs steadily increased throughout the grades in every subject (i.e. $5.5 \%$ of grade 8 science enrollees were entrepreneurs, but $13.1 \%$ of grade 12 science enrollees were entrepreneurs). Meanwhile, refugees dropped from a 7.5-8.5\% share of the sample across the four subjects in grade 8 to a 1.5 to $<6 \%$ share of the sample by grade 12. Regular immigrants retained stable shares of the total numbers at each grade level.

Nonetheless, it is difficult to understand the extent to which SES accounts for ethnocultural variation in achievement. First, as Gunderson (2007) acknowledges, immigrant status is an imperfect indicator of SES. The regular immigrant group certainly represents wide variation in socioeconomic reali- 
ties, and a substantial proportion of refugees are not socioeconomically disadvantaged. Second, immigrant status is not systematically controlled in the statistical analyses, nor are the precise numbers of students reported from each immigration status in each ethnocultural group. Finally, the numbers of entrepreneur-class immigrants above account for fewer than one third and one fifth of students in the Chinese-speaking groups. It is unclear if they are responsible for the group average being as high as it is.

Toohey and Derwing (2008) also wonder if the immigration influx of "wealthy Asians" to the lower mainland might be masking the difficulties of less economically advantaged students. Like Gunderson's (2007) findings, their data permitted only an estimate of SES by immigration status, and immigration status itself was not tied to individual students, but rather "grouped generally" (p. 185) with the ethnocultural group, according to data from Citizenship and Immigration Canada. This being said, the home-language groups most often characterized by independent status (high SES) indeed displayed the highest rates of graduation. Toohey and Derwing also reported graduation rates from high- and low-SES schools. Here their indicators of school SES were based on face characteristics of surrounding housing and the commonsense East (not wealthy)/West (wealthy) boundary widely believed to divide Vancouver. Whereas one of the high-SES schools had a much higher ESL graduation rate than one of the low-SES schools, the other two schools' rates were nearly identical; there was no SES advantage.

Other studies have also measured SES only at neighborhood and school levels. Anisef et al. (2010) measured neighborhood-level SES and found that the proportion of people living below the Low Income Cut Off (LICO) in a student's neighborhood was a statistically significant predictor of dropout for immigrant students. Nonetheless, with all control variables in place, including family structure and level of streaming, neighborhood SES explained only a modest $5 \%$ of the variation. Although SES seems to matter, the small effect of this indirect indicator of family income provides only modest support for this hypothesis. Garnett et al. (2008) found through multivariate analysis that school SES predicted enrollment, but not performance in senior math and sciences and failed to eradicate ethnic effects. However, they too relied on a single indicator the percentage of families on income assistance to dichotomize schools into high and low SES.

Garnett (2010) measured socioeconomic status by the average income for the family's 2001 postal code on the 2001 Census. It is impossible to be certain, however, if this measure captures neighborhood or family-level effects. Overall, Garnett found that family-level SES was only weakly associated with ESL graduation; and Garnett and Aman (2011) reported no association with the same indicator. However, the same indicator was much more strongly correlated with graduation of native-English-speakers. Garnett speculates that native speakers without a high school diploma may have more 
opportunities in the labor market than ESL students. Enrollment in English 12 , the typical option for BC graduation's mandatory Language Arts requirement, produced a similar result. Interestingly, the exact opposite effect was obtained when predicting enrollment and performance in mathematics. Here a robust correlation was found between achievement and family-level average income in the ESL communities, but not among NESs. Again, Garnett and Aman (2011) reported a similar finding. Overall, it appeared that graduation was a highly desirable minimum standard throughout the income strata of the various ESL communities; however, students from higher-income families participated more often and performed more successfully in mathematics, perhaps partly as a result of the "multiple tutors" that Gunderson suggests such students may employ.

Garnett (2010) reports substantial variation in the magnitude of SES effects among the various ethnocultural subgroups. When cross-tabulating the participation and performance of the subgroups according to high ( $>50$ th percentile) or low ( $<51$ st percentile) family income, he discovered that income level was a strong predictor of Spanish-speakers' outcomes (e.g., high-income Math 12 mean score +13 ) but a trivial or non-predictor of Chinese-speakers' outcomes (e.g., high-income Math 12 mean score +4). SES effects among other ethnocultural groups fell between those of these two groups and sometimes traveled in an unexpected direction. Similarly, only the Spanish-speakers showed a non-trivial SES advantage in six-year graduation rates (high income $+10 \%)$. Generally, Garnett and Aman (2011) replicated Garnett et al.'s (2008) findings: for SES in variables that they derived in the same way, they found them either statistically insignificant or significant but weak predictors of graduation in the ESL population.

Overall, Garnett (2010) and Garnett and Aman (2011) interpret SES as a weaker predictor of trajectories than Gunderson (2007), Toohey and Derwing (2008), or Anisef et al. (2010), finding that family SES mildly improved, but only partly accounted for a consistent pattern of ethnocultural disparities. Nonetheless, income is only one indicator of SES. Parents' educational level is probably a better predictor of school achievement, and income and education are probably not as tightly correlated in the immigrant community as they are in the mainstream. Therefore, the mild effects of SES operationalized only as income discovered in the Garnett (2010) studies and Anisef et al. (2010) may be underestimated.

Furthermore, Garnett's (2010) three highest-achieving ethnocultural groups, the Chinese, Koreans, and Persians, were the three with the highest proportions living in high-income postal-code areas. He posits that students from ethnocultural groups for whom upward social mobility is clearly tenable may invest more highly in school regardless of their personal socioeconomic reality. This explanation accounts for the large variation in trajectories that appears to be correlated with socioeconomic status among diverse ethnocul- 
tural groups and the simultaneously modest number of variations predicted by socioeconomic status within most ethnocultural groups. Gunderson's (2007) interview data with a low-achieving Vietnamese girl skeptical of the utility of schooling support this hypothesis. In any case, all studies make clear that better data on SES are necessary if the true degree of its effects is to be uncovered. In particular, no study has directly measured income or education at the level of individual families. Furthermore, attention must be paid to the fact that for many immigrants, home educational background and social class may not be tightly correlated with income in the host country.

\section{Even Successful High School Immigrants May Struggle in University}

By many measures, the members of Generation 1.5 who were accepted and enrolled in university would be considered successful. Yet some research suggests that equity gaps, predictable by ethno-racial origins, also exist at the tertiary level. Grayson (2009) found that in general, ESL students at university did not achieve GPAs comparable to those of native-born Canadians. Furthermore, among males, students of Black, Korean, South Asian, and Southeast Asian origin scored lower than European-origin students; and among females, only Arab/West Asian, Japanese, Korean, and Other scored lower than European-origin students.

Fox (2005) also found that ESL students in university lagged behind native speakers. When comparing students who had been in Canadian high schools from three to five years before entering university, he did not find statistically significant differences in GPAs among these ESL groups, but did find large differences between all three of these ESL groups who averaged C- to D+ and the general population who averaged B-.

Roessingh and Douglas (2011) offer convincing proof that linguistic challenges do hamper academically competent Generation 1.5 students in university. They found that $30 \%(n=675)$ of ELL students entering the University of Calgary failed their high school English diploma exams, and hundreds more achieved a minimal pass. Overall, they noted that graduating ELLs entering the University had about a grade 9 reading level, whereas a standard first-year textbook demands a "grade 20" level of proficiency. They conclude that ELLs are at risk of dropping out of university.

\section{What are Our Weaknesses?}

Categorizing Generation 1.5 students with labels like immigrant and ESL without recognizing the wide and predictable variations that occur in such classifications is our obvious weakness. This oversight prevents identification of groups who are vulnerable to educational failure due to: (a) disadvantaged educational backgrounds indicated by ethnocultural background; and (b) limited proficiency in the language of instruction; which contributes to (c) our continued underpreparation of teachers. 


\section{Underserving Immigrants with Disadvantaged Educational Backgrounds}

Although socioeconomic status as indicated by income is often a modest and inconsistent predictor (Garnett, 2010; Garnett \& Aman 2011; Toohey \& Derwing, 2008) or a plausible but statistically untested predictor (Gunderson, 2007), the specific ethnocultural achievement gaps across the studies reviewed suggest that we may inadequately integrate children whose prior educational experiences might not have prepared them sufficiently for school.

The relative success of the integration of immigrant students into Canadian schools is probably owing in part to an immigration policy that has encouraged "the best and brightest" to leave their home countries and settle in Canada. Furthermore, the points system has brought large numbers of immigrants from particular regions with what the Organization for Economic Co-operation and Development's (OECD, 2010) PISA scores indicate are well-developed economies and educational infrastructures such as Hong Kong and South Korea. It is not surprising that the dominant pattern of children of parents who are educated and/or who value education is scholastic success. These children have the prior knowledge, resources, and values from home that encourage academic attainment.

The studies reviewed here show that ethnocultural groups in which the dominant characteristics are probably not high levels of rigorous home-country education fare more poorly in Canadian schools. In Vancouver, this includes the Vietnamese and Spanish-speakers (Garnett, 2010; Gunderson, 2007; Toohey \& Derwing, 2008), comprising disproportionately refugees, whose schooling may have been interrupted (Gunderson, 2007). Filipino students are also at risk of poorer than average outcomes (Garnett; Garnett et al., 2008; Gunderson) and are found disproportionately in economically disadvantaged schools and neighborhoods (Garnett \& Aman, 2009).

In Toronto, students from the English-speaking Caribbean, Africa, and West Asia are at the greatest risk of dropout. Students from these economically disadvantaged regions also live in the poorest neighborhoods of their new cities (Anisef et al., 2010). Spanish- and Portuguese-speakers also have high dropout rates in Toronto and are frequently found in socioeconomically disadvantaged schools (Anisef et al., 2009).

In Montreal, Black African and Caribbean students (McAndrew et al., 2005) and speakers of Tamil, Portuguese, Creole, and Spanish (McAndrew et al., 2009) have lower than average outcomes and are all overwhelmingly disproportionately represented in socioeconomically disadvantaged schools.

In sum, although the socioeconomic indicators available have appeared weak where they have been statistically tested, the most vulnerable groups are undeniably from the more disadvantaged regions of the globe and tend in Canada to be settled in disadvantaged neighborhoods. Their educational vulnerability has been masked by the large numbers of immigrants from, rel- 
atively speaking, more affluent backgrounds. If education is to reduce inequality, these groups must be better served.

\section{Underserving Immigrants with Low English Proficiency}

Notwithstanding the Chinese resilience to limited English proficiency in Garnett (2010) and the non-significance of the insufficiently sensitive ESL service ever indicator as a predictor variable (Anisef et al., 2009), four studies with adequate language proficiency variables clearly indicate that limited proficiency in the language of instruction at the beginning of high school predicts a high risk of educational failure.

In Watt and Roessingh (1994, 2001), over 90\% of beginner ESL students failed to graduate. In Derwing et al. (1999) $60 \%$ of students who needed ESL in high school failed to graduate. In Garnett (2010), the less sensitive indicator of needing two or more years of ESL during and after grade 8 revealed $42 \%$ of non-Chinese ESL students did not graduate in five years; this number was reduced to $32 \%$ when an extra year to graduate was accounted for.

Moreover, Garnett (2010) showed that mean scores dropped for beginner ESL students across subject areas, dramatically for some ethnocultural groups, and participation in academic courses dropped for some ethnocultural groups. Watt and Roessingh also showed that of the ESL students who graduated, a disproportionate number did so with a general rather than advanced diploma.

Despite the ability of some groups like the Chinese in Vancouver to withstand the challenges posed by limited proficiency in the language of instruction, the educational systems generally appear to underserve those who face serious linguistic obstacles. This result is lost when these students are categorized with "all immigrants," many of whom are fluent in the languages of instruction.

This problem appears to continue into university, where students whose academic competence often displayed through high math scores (Roessingh \& Douglas, 2011) led to their acceptance in postsecondary institutions, appear at risk of dropout due to the greater linguistic challenges of tertiary education.

\section{Underpreparing Teachers}

The school-level personnel with the most direct effect on ESL students are teachers. If we wish to reduce the mean score gaps among some ethnocultural groups and mainstream baselines (Garnett, 2010), more and better professional development is probably an important investment.

Cummins' (1997) believes that teachers' high expectations and goals for minority students are critical to the success of minorities. In mainstream teachers' daily micro-interactions with disadvantaged students, expectations for success need to be communicated and meaningfully supported with actions. 
This process begins with preservice teachers examining their own beliefs, a process that should continue throughout their professional careers. Veteran teachers who began careers before the contemporary influx of immigration may particularly need such inservice. Even after nearly two decades of largescale immigration, many mainstream teachers retain two characteristics: (a) inadequate training for meeting the needs of ESL students, and (b) the related belief that ESL students are not their responsibility.

For example, in a survey of 276 mainstream teachers in the US, Reeves (2006) found that most did not believe that English-language learners should be mainstreamed until they had gained a base amount of linguistic fluency. Derwing et al. (1999) described a teacher's fear that English-language learners brought down the class average. Reeves also reported that most teachers felt that they did not have adequate professional training to serve ESL students appropriately, but were ambivalent about receiving more training (Clair, 1995).

In fact, most Canadian universities include in their teacher education programs social justice components designed to open preservice teachers' minds to the realities of diverse student populations; their effectiveness has not been empirically verified in the Canadian literature, although Youngs and Youngs (2001) found that exposure to cultural diversity through ESL training, multicultural coursework, and foreign-language experiences increased teachers' positive attitudes toward ESL students. Unfortunately, however, universities do little to prepare preservice teachers in concrete methods of communicating mainstream course content to ESL students. Such classes exist, but are rarely mandatory. For teachers who plan to work in large urban school boards, they probably should be.

Furthermore, I have observed that in many universities' teacher education programs, ESL is not considered a "teachable subject" in which prospective teachers may major in their preservice year. If teachers want an ESL credential, they must return to university after completing their teacher education programs. Although some teachers take this path and most districts give priority to those with appropriate credentials, the restriction to majoring in ESL education almost certainly reduces the supply of qualified ESL teachers. As a result, many school programs are staffed by well-meaning but underprepared ESL teachers.

\section{What Appear to be the Key Policies and Practices That Do, or Could, Produce Favorable Outcomes?}

The empirical studies reviewed here do not include in-depth analyses of policy contexts and effective teaching practices. Nevertheless, their findings, along with the strengths and weaknesses that they reveal, indicate the importance of a few basic best practices that are implemented to greater or lesser degrees across Canadian jurisdictions. 


\section{Provide Adequate Time to Receiving Support in the Language of Instruction}

First, to succeed, ESL students generally require a generous amount of time receiving additional language support. Schools need extra money to provide this support. Watt and Roessingh (2001) tracked students in Calgary before and after budget cuts. During post-budget cuts, the time dedicated to ESL programming was diminished by $50 \%$. One result of these cuts was a large spike in how quickly ESL students dropped out of high school. Watt and Roessingh believed that too-early integration into the mainstream effectively pushed ESL students out of school faster.

Similarly, Gunderson (2007) observed that South Asian and Filipino students began to disappear from his data quickly when additional ESL support was withdrawn. Garnett (2010) suggested that achievement gaps between ESL students who had been in Canadian schools for over five years and NESs implied that ESL support might have to continue longer than it does. In her examination of successful ESL students, Roessingh (2006) noted that their contact time with an ESL teacher was not lengthened, but intensified from 350 hours per year to 700 hours per year.

To the degree that outcomes are favorable, the additional funding offered to school boards by ministries of education to provide additional language support time to immigrant students clearly appears beneficial. BC, Ontario, and recently Alberta all offer relatively generous supplementary funds to school boards based on the number of ESL and/or immigrant students enrolled for up to four and five years of their enrollment. Some argue that current funding does not meet the needs of all immigrant students because it is not enough (Derwing et al., 1999; Kouritzin, 2004) or accountable (Canadian Broadcasting Corporation [CBC] News, 2007), but certainly when it has been unstable, students have suffered (Watt \& Roessingh, 2001).

Fox (2005) and Roessingh and Douglas (2011) provide evidence that well-timed language instruction should probably also be offered at the tertiary level. Many for whom English is not a first language appear at risk of not completing valued university degrees. It appears that the academic competence necessary for university entrance must be complemented with increased linguistic competence to meet the language demands of university study.

\section{Provide Time to Complete Course Requirements}

Second, ESL students need time to complete high school programs. Watt and Roessingh (1994) observed that the three-year program in Calgary (grades 10-12) took an average ESL student four to five years to complete. Furthermore, $50 \%$ of the eventual graduates were over 19, the age cap that Alberta eventually instituted, when they graduated. Derwing et al. (1999) also showed that an age cap prevented ESL students from graduating. 
Garnett (2010) shows the substantial increase in equity to beginner ESL learners that results from BC's policy of permitting six years from entering grade 8 to achieve graduation. Whereas NES six-year graduation rates jump to $74 \%$ from the five-year rate of $68 \%$, among certain ethnocultural groups the jump is 12-14 percentage points. For example, graduation rates of Persian students jump from $58 \%$ in year 5 , far from the NES baseline, to $72 \%$ in year 6 , almost equal to the NES baseline. Allowing time for graduation raises the bar for all students and narrows the equity gaps among students. A similar pattern is seen in data from Montreal (McAndrew et al., 2009).

Policies that allow extra time and alternate venues for graduation are critical to immigrant students. The jurisdictions that receive the most immigrant students are reasonably good at providing this time. For example, although it would be preferable not to force immigrant and other students out of school at age 19 as generally happens in BC, alternate paths to graduation nonetheless exist in that province.

Improving outcomes depends on addressing the weaknesses described above: integrating students who enter schools with educational and linguistic disadvantages and finding ways to foster professional development. At the policy level, these goals may be reached through more effective funding and accountability mechanisms in professional growth.

\section{Direct Funding Appropriately}

The first step here is to disaggregate data for decision-making. There is limited value in making decisions for Generation 1.5 based solely on immigrant or ESL categorizations when so much variation occurs beneath these labels; the educational needs and subsequent achievements of a Somalian refugee and a Taiwanese entrepreneur's child are not similar.

Therefore, resources should be directed to those most in need. The studies reviewed consistently identify particular subgroups at risk of non-completion of high school. By contrast, other subgroups by most measures outperformed Canadian-born students. In a universe of scarce resources and school systems concerned with equity, targeting a larger share of resources to underperforming groups of students makes more sense.

The implication is not that boards develop explicit policies for diverse ethnocultural groups. Rather, they should assess their own student populations through data and consultations with teachers, counselors, and administrators, and then use their funds to make the decisions that extend the support required. As Goddard and Hart (2007) suggest, if school leaders assume that ethnoculturally diverse students all arrive in school equally ready to learn and are thus "treated exactly the same as everyone else" (p. 21), they will only reproduce the dominant classes.

Although the above recommendation requires allowing more flexibility for funds received, paradoxically, there may currently not be enough ac- 
countability to ESL students for the funding that they generate. It appears sometimes to be spent on other programs. In 2007, the chair of the York District School Board claimed:

The pattern in the province has been that many boards have chosen to use those [ESL] funds for other things, and the natural consequence of that is that the new English language learners in the province have not been appropriately well-served. (CBC, 2007)

Ideally, funding to support immigrant students would be flexible enough to address the places of greatest need, but accountable enough to ensure that it not be spent on a competing priority.

\section{Address the Areas of Need Intensely}

Among many ethnocultural groups across the studies, better English proficiency was an excellent predictor of better trajectories. Also, the academic advantages of the high-performing ethnocultural groups were probably owing in large measure to their previous instruction. In sum, schools can reduce substantive inequality of opportunities and outcomes by providing increased instructional support in language and content development to vulnerable ESL students.

Regarding English-language proficiency, Roessingh (2006) affirms that the highly successful ESL students whom she taught received double her province's mandatory ESL teacher contact hours. Because increasing teacher contact hours increases the need for scarce resources, the case for targeting support to the students with most need is bolstered.

Regarding content instruction, a wide body of literature over the past 25 years has also discussed the importance of ensuring that curricular-content knowledge is taught to ESL students simultaneously with their English-language instruction (Brinton, Snow, \& Wesche, 2003; Chamot \& O'Malley, 1994; Mohan, 1986). ESL students do not have time to wait until they have mastered English before they can begin their content-area studies, and many are obviously coming to school with content deficits. Predictably, when examining the navigation of ESL students through high school, Derwing et al. (1999) note, a "stronger link between ESL and content curricula is necessary" (p. 545) to promote success.

\section{Encourage Professional Development}

As discussed above, most mainstream teachers have little or no professional training in ESL pedagogy, and most teacher education programs do not offer ESL as a major teachable subject. Urban school boards could increase ESL knowledge in their human resources by insisting and widely publicizing that prospective teaching employees require coursework in teaching to ESL pop- 
ulations. This additional study would pressure universities to provide such courses. Similarly, senior school board officials could demand that their administrator candidates articulate a plan for the support of its immigrant students as a criterion for their promotion.

\section{Where is More Research Needed?}

The findings reviewed here suggest no shortage of future research directions in the field of Generation 1.5's academic trajectories in Canadian schools. As I have mentioned elsewhere (Garnett, 2010), there is a need to replicate some of these studies across diverse geographical and chronological cohorts of students. Many studies reviewed here are dependent on BC data, for example. Second, the interaction of gender with ethnocultural background has not been substantively examined. Early indications are that gender plays a far stronger role in some ethnocultural groups than in others. Third, although the school-orientation of Chinese families has been documented ( $\mathrm{Li}, 2001)$, little research documents the school experiences of Vietnamese, Filipino, or Spanish-speaking immigrant students in Canada. This study suggests that the experiences of these groups require closer examination to uncover what forces they feel account for their comparative lack of success in the school system. Further research might also examine the characteristics of successful members of these less successful communities. On a technical level, data refinements would certainly help us to understand the role of the important SES variable in understanding Generation1.5's outcomes. No study reviewed here was able to measure family-level SES directly. If decision-makers wish to use evidence to inform policy, they may wish to collect such data more systematically.

\section{The Author}

Bruce Garnett has a doctorate in education from the University of British Columbia. He taught ESL to adolescents and adults for nearly 20 years. He is currently a secondary school vice-principal.

\section{References}

Anisef, P., Brown, R., Phythian, K., Sweet, R., \& Walters, D. (2010). Early school leaving among immigrants in Toronto secondary schools. Canadian Review of Sociology, 47(2), 103-128.

Anisef, P., Brown, R., Sweet, R., \& Walters, D. (2009). Educational pathways and academic performance of youth of immigrant origin: Comparing Montreal, Toronto and Vancouver (Toronto Site Report). Ottawa, ON: Canadian Council on Learning/Citizenship and Immigration Canada.

Arnold, D.H., \& Doctoroff, G.L. (2003). The early education of socioeconomically disadvantaged children. Annual Review of Psychology, 54, 517-545.

Brinton, D., Snow, M., \& Wesche, M. (2003). Content-based second language instruction. New York: Newbury House. 
Brown, R.S. (2006). The grade 9 cohort study: A five-year analysis, 2000-2005. Research Today, 2(1). Available:

http://www.tdsb.on.ca/wwwdocuments/about_us/external_research_application/docs /grade9cohortvol2iss1.pdf

Canadian Broadcasting Corporation (CBC) News. (2007, April 18). Ontario eyes tighter rules for ESL funding. Available: http://www.cbc.ca/canada/toronto/story/2007/04/16/ontario-esl.html

Chamot, A., \& O'Malley, M. (1994). The CALLA handbook: How to implement the Cognitive Academic Language Learning Approach. Reading, MA: Addison Wesley.

Clair, N. (1995). Mainstream classroom teachers and ESL students. TESOL Quarterly, 29, 189-197.

Cummins, J. (1997). Minority status and schooling in Canada. Anthropology and Education Quarterly, 28, 411-430.

Derwing, T.M., DeCorby, E., Ichikawa, J., \& Jamieson, K. (1999). Some factors that affect the success of ESL high school students. Canadian Modern Language Review, 55, 532-547.

Fox, J. (2005). Re-thinking second language (L2) admission requirements: Problems with language residency criteria and the need for language assessment and support. Language Assessment Quarterly, 2(2), 85-115.

Garnett, B. (2010). Toward understanding the academic trajectories of ESL youth. Canadian Modern Language Review, 66, 677-710.

Garnett, B., Adamuti-Trache, M., \& Ungerleider, C. (2008). The academic mobility of students for whom English is not a first language: The roles of ethnicity, language, and class. Alberta Journal of Educational Research, 54, 309-326.

Garnett, B., \& Aman, C. (2009). Educational pathways and academic performance of youth of immigrant origin: Comparing Montreal, Toronto and Vancouver (Vancouver Site Report). Ottawa: Canadian Council on Learning/Citizenship and Immigration Canada.

Garnett, B., \& Aman, C. (2011, winter). Variations in the graduation rates and educational pathways of English language learners in Metro Vancouver. Canadian Issues, 49-56.

Goddard, T., \& Hart, A. (2007). School leadership and equity: Canadian elements. School Leadership \& Management, 27(1), 7-20.

Grayson, J.P. (2009). Language background, ethno-racial origin, and academic achievement of students at a Canadian university. International Migration, 47(2), 33-67.

Gunderson, L. (2007). English-only instruction and immigrant students in secondary schools: A critical examination. Mahwah, NJ: Erlbaum.

Kouritzin, S.G. (2004). Programs, plans, and practices in schools with reputations for ESL student success. Canadian Modern Language Review, 60, 481-499.

Li, J. (2001). Expectations of Chinese immigrant parents for their children's education: The interplay of Chinese tradition and the Canadian context. Canadian Journal of Education, 26, 477-494.

McAndrew, M., Ait-Said, R., Ledent, J., Murdoch, J., Anisef, P., Brown, R., Sweet, R., Walters, D., Aman, C., \& Garnett, B. (2009). Educational pathways and academic performance of youth of immigrant origin: Comparing Montreal, Toronto and Vancouver. Ottawa: Canadian Council on Learning/Citizenship and Immigration Canada.

McAndrew, M., Ledent, J., \& Ait-Said, R. (2005). L'école québécoise assure-t-elle l'égalité des chances? Le cheminement scolaire des jeunes noirs au secondaire [Equal opportunity in Quebec high-schools? The experience of Black youth]. Cahiers Québécois de Démographie, 35(1), 123-148.

McAndrew, M., Ledent, J., Murdoch, J., \& Ait-Said, R. (2009). Educational pathways and academic performance of youth of immigrant origin: Comparing Montreal, Toronto and Vancouver (Toronto Site Report). Ottawa: Canadian Council on Learning/Citizenship and Immigration Canada. 
Mohan, B. (1986). Language and content. Reading, MA: Addison-Wesley.

Organization for Economic Co-operation and Development (OECD). (2010). PISA 2009 results: What students know and can do Student performance in reading, mathematics and science (vol. 1). Available: http://www.oecd.org/dataoecd/10/61/48852548.pdf

Portes, A., \& Hao, L. (2004). The schooling of children of immigrants: Contextual effects on the educational attainment of the second generation. Proceedings of the National Academy of Sciences of the United States of America, 101(33), 11920-11927.

Portes, A., \& Rumbaut, R. (1990) Immigrant America. Los Angeles, CA: University of California Press.

Radwanski, G. (1987). Ontario study of the relevance of education and the issue of dropouts. Toronto, ON: Ontario Ministry of Education.

Reeves, J.R. (2006). Secondary teacher attitudes toward including English-language learners in mainstream classrooms. Journal of Educational Research, 99(3), 131-142.

Roessingh, H. (2006). The teacher is the key: Building trust in ESL high school programs. Canadian Modern Language Review, 62, 563-590.

Roessingh, H., \& Douglas, S. (2011). English language learners' transitional needs from high school to university: An exploratory study. Journal of International Migration and Integration, $1-17$.

Samuel, E., Krugly-Smolska, E., \& Warren, W. (2001). Academic achievement of adolescents from selected ethnocultural groups in Canada: A study consistent with John Ogbu's theory. McGill Journal of Education, 36(1), 61-73.

Toohey, K., \& Derwing, T.M. (2008). Hidden losses: How demographics can encourage incorrect assumptions about ESL high school students' success. Alberta Journal of Educational Research, 54, 178-193.

Watt, D., \& Roessingh, H. (1994). ESL dropout: The myth of educational equity. Alberta Journal of Educational Research, 40, 283-296.

Watt, D., \& Roessingh, H. (2001). The dynamics of ESL drop-out: Plus ça change ... Canadian Modern Language Review, 58, 203-222.

Worswick, C. (2001). School performance of the children of immigrants in Canada, 1994-98. Ottawa: Statistics Canada.

Youngs, C.S., \& Youngs, G.A. (2001). Predictors of mainstream teachers' attitudes toward ESL students. TESOL Quarterly, 35, 97-120. 